\title{
Constraints Faced by the Betel Vine Growers in Nadia District of West Bengal, India
}

\author{
Manaranjan Biswas ${ }^{1}$, Anindita Saha ${ }^{1}$ and Samir Ranjan Dash ${ }^{2 *}$ \\ ${ }^{1}$ Department of Agricultural Extension, Palli Siksha Bhavana (Institute of Agriculture), \\ Visva-Bharati, Sriniketan- 73123, India \\ ${ }^{2}$ KVK, Malkangiri, Odisha OUAT, Bhubaneswar-751003, India \\ *Corresponding author
}

\begin{tabular}{|l|}
\hline Ke y w o r d s \\
Knowledge \\
Information \\
System, Transfer of \\
knowledge, \\
Employment, \\
Constraints
\end{tabular}

A B S T R A C T

Betel vine (Piper betle L. ) in India is grown as an important cash crop across the states, of Andhra Pradesh, Karnataka, Kerala, and Tamil Nadu, Assam, Bihar, Madhya Pradesh, Maharashtra, Odisha, Tripura, Uttar Pradesh and West Bengal. The Indian betel leaves are in great demand in several countries like where demand far exceeds the local supply. Cultivation of betel vine is one of the most important horticultural crops, is gradually increasing its popularity in the Nadia districts as cash crop. A study was undertaken in Nadia district of West Bengal for analysis of constraints faced by the farmers in betelvine cultivation covering four blocks Karimpur 1, Karimpur 2, Krishnagang and Chakdaha taking eight villages selected purposively where the crop is grown as a major crop. A total 200 betel vine growers were selected randomly from eight villages. It is observed that investment on betel vine cultivation is profitable and attractive in these areas but due to inadequate information regarding Betel vine production, almost cent per cent growers were using their own traditional planting material since long and growing their crops with their indigenous knowledge, skill and their past experiences. They have little knowledge regarding the improved method of cultivation. The study further indicated that the second most important constraint found was high cost of Boroj construction followed by lack of adoption of plant protection measures by the farmers. Based on the study following recommendations are made for enhancing the profitably of betel vine cultivation in the study area that the farmers should have easy access to information in related to production management and marketing aspects.

\section{Introduction}

Betelvine or Pan (Piper betel L) belongs to the family Piperaceae and is a perennial aromatic creeper grown for its leaves. It is an important commercial crop in India, Bangladesh and Srilanka and also most profitable amongst all cultivated crops and is grown as an cash crop across the states, of Andhra Pradesh, Karnataka, Kerala, and Tamil Nadu, Assam, Bihar, Madhya Pradesh, Maharashtra, Odisha, Tripura, Uttar Pradesh and West Bengal. India is the largest producer of betel leaves in the world. The Indian betel leaves are in great demand in several countries like where demand far exceeds the 
local supply. Consequently, leaves worth about Rs. 30-40 million are exported to European countries (Guha, 2006). It is an opportunity for the Indian betel vine growers as well as seller to earn more profit not only within the country but also by exporting to European countries. Further, as far as the national employment generation is concerned, about 20 million people derive their livelihoods directly or indirectly from production, processing, handling, transportation and marketing of betel leaves in India (Guha, 2006). It is one of the important commercial crops grown mostly by Pakistan, Bangladesh, Indonesia, Malaysia, Burma and Thailand small and marginal farmers across the country. On an average about $66 \%$ of such production is contributed by the state of West Bengal where it is cultivated on about 20,000 ha encompassing about 4-5 lakh employing about the same number (4-5 lakh) of agricultural families (Guha, 2006). Betelvine cultivation has brought a paradigm shift in the farm economy West Bengal and offers perennial employment and income to small and marginal farming community because of its capital and labour intensive characteristic (Chandra\& Sagar, 2004). Betel vines are to be grown in closed conservatories, locally called Baroj (artificial conservatory for betelvine cultivation) with a view to protect the vines from desiccation in summer, retains maximum moisture condition, permits little light and cold in winter, are generally rectangular in shape and its normal size is often 50 to 30 sq. meters. Baroj are generally small because its maintenance ought to be easy and their cost of erection is within manageable limits. Cultivation of betel vine as one of the most important horticultural crops and gradually gaining its popularity in this area as cash crop. Betel vine cultivation has its own overall and holistic socioeconomic impact on the farming community. Nadia is characterized with multi-faceted problems such as low crop productivity due to inherent problem of soil and hence low returns. Farmers depend on natural resources completely and are able to cultivate only a single crop during the rainy season that is they are bound to mono-cropping (Mandal 2013). It is the most important cash crop and its cultivation has already brought a perceptible and conspicuous change in the livelihood security of farmers in region and its farming population. Farmers are selling their produce at local markets as well as at distant markets like Karimpur and Shimurali or in other markets.

However, the betel vine is susceptible to damage caused by insects, rain and wind. Shortage of irrigation can also cause hindrance for the growth of betel vine. High cost of fertilizer and pesticide, fluctuating price, many intermediaries, inadequacy of finance, transport, absence of grading, lack of storage facility also cause of great loss to farmers. Chewing is slowly replaced by the areca product made for chewing, which leads to decrease in demand for betel leaves. In view of the above problems in betel vine cultivation the current study was undertaken for identifying the constraints in production and marketing of betel vine in the study area. The constraints were operationally defined as the difficulties experienced by the farmers in adoption of improved production technology. In the present study efforts have been made to know the constraints faced by the Betel vine growers.

\section{Materials and Methods}

The present study was undertaken to identify constraints of Betel vine growers in Nadia district of west Bengal. Multi-stage stratified sampling procedure was employed for selection of blocks, villages and betel vine growers. This study has been conducted in the Nadia district of West Bengal covering four 
blocks namely Karimpur 1, Karimpur 2, Krishnaganj, and Chakdah. The blocks were selected purposively because these blocks are leading in terms of area and production of betel vine in the district and also presence of wholesale market in Karimpur town. A sample size 200 betetlvine growers were randomly selected from eight villages covering four blocks were selected as the respondents. Although betel vine cultivation is profitable, but many farmers were switching over to other crops from betel vine due to lack of money/credit facilities and also high price uncertainty in the local market (Absar, 2015). Considering this, the study was organised with an objective to study the constraints faced by farmer according to ranking. The primary data were collected from the sample farmers on pre-structured schedules through personal interview method for the agricultural year 2015-2016. For measurement of these variables a list of various constraints was prepared in consultation with the farmers, extensionists and researchers. In order to study the frequency of constraints, one frequency continuum was prepared against each constraint as most often, often, some times and never, and assigned score were 4, 3, 2, 1 respectively. The total preference score for each content was calculated and mean sore for particular constraints was worked out then ranking was done as the basis of $\mathrm{CV}$ percentage.

\section{Results and Discussion}

Detailed information on betel vines such as starting year, list of various constraints was prepared after detail discussion with the farmers. Then farmers were asked to assign rank to these constraints during personal interview. Based on the rank assigned by farmers, constraints have been prioritized through computing rank following standard procedure and with the help of table. The order of merit assigned by the respondents was changed in to ranks by employing the formulas as, Percent position. The position of each rank is converted into score by referring tables given by Garret and Woodworth (1969). Then for each factor, the score of individual respondents are added together and divided by the total number of respondents for whom scores are added. The mean scores for all the factors are ranked by arranging in descending order.

The selected growers were asked to indicate the constraints through a structured suitable scheduled. The information collected by interviewing the selected Betel vine growers and tabulated them to identify the most important constraints by ranking them in the sampled areas. The suitable statistical tools like percentage, mean, Standard deviation and CV\% were used for analysis and interpretation of the data. On the basis of the mean score and Co-efficient of variance rank order was made. The variables were ranked according to their consistency, the item then securing lowest $\mathrm{CV} \%$ has given first rank and so on. The collected data were analyzed and rank was determined and presented in Table1 .

From the above table it was inferred that almost all enlisted constraints had been faced by the farmers in betel vine cultivation. However, in-adequate information regarding betel vine production was the main constraint expressed by the farmers. It may be observed from above table that, in adequate information regarding Betel vine production $(13.501 \%$ ) in the sampled areas, was the main constraint expressed by the farmers. Almost cent percent growers were using their own traditional planting material since long and growing their crops with their indigenous knowledge, skill and their past experiences. They have little awareness regarding the improved method of cultivation. The second most constraint 
reported by the farmers was high cost for construction of Baroj (21.56\%) as the Betel vine crops entirely dependent on construction of Baroj. The results are in agreement with the findings of Balasubrahmanyam et al., (1990).

Table.1 Constraints faced by the Betel vine growers

\begin{tabular}{|c|c|c|c|c|}
\hline \multirow[t]{2}{*}{ Constraints } & \multicolumn{4}{|c|}{ Frequency continuum } \\
\hline & Mean & Std Error & $\mathrm{CV} \%$ & Ranking \\
\hline Lack of time & 1.085 & 0.022 & 28.89 & ix \\
\hline $\begin{array}{l}\text { Inadequate information regarding betel vine } \\
\text { production }\end{array}$ & 2.025 & 0.019 & 13.50 & $\mathrm{i}$ \\
\hline Credible source of knowledge $\&$ information & 2.095 & 0.038 & 25.59 & vi \\
\hline Lack of research regarding betel vine & 2.790 & 0.059 & 29.75 & xii \\
\hline High cost for construction of baroj & 3.560 & 0.054 & 21.56 & ii \\
\hline Lack of plant protection measure & 3.650 & 0.056 & 21.58 & iii \\
\hline Lack of Suitable and own land of farmers & 2.400 & 0.075 & 44.20 & xvi \\
\hline Lack of farmer association/organizations & 1.640 & 0.045 & 39.16 & $\mathrm{xV}$ \\
\hline Inadequate / transport/ storage facilities & 2.130 & 0.056 & 37.44 & xiii \\
\hline Lack of government financial support/ bank loans & 2.620 & 0.054 & 29.28 & $\mathrm{x}$ \\
\hline $\begin{array}{l}\text { Lack of facility provided by Assistant Director of } \\
\text { Agriculture / Horticulture Development Officer etc }\end{array}$ & 3.205 & 0.059 & 25.85 & vii \\
\hline Low frequency visit by ADA/KPS & 3.395 & 0.054 & 22.46 & iv \\
\hline In adequate procurement price & 1.865 & 0.072 & 54.46 & xviii \\
\hline Lack of communication facilities to farmers doorstep & 1.580 & 0.038 & 33.79 & xiii \\
\hline $\begin{array}{l}\text { Negative attitude of extension worker to the farmers } \\
\text { problems }\end{array}$ & 2.250 & 0.041 & 25.88 & viii \\
\hline Lack of interest of extension personnel & 2.890 & 0.049 & 23.98 & $\mathrm{v}$ \\
\hline Lack of incentives & 3.385 & 0.069 & 28.96 & $\mathrm{xi}$ \\
\hline In adequate knowledge of Local dealer & 2.355 & 0.095 & 56.77 & xix \\
\hline Lack of skilled labour & 1.795 & 0.048 & 37.58 & xiv \\
\hline Lack of storing facility & 2.090 & 0.069 & 46.55 & xvii \\
\hline High cost of labour & 2.325 & 0.046 & 28.25 & xii \\
\hline
\end{tabular}

The results given in above Table revealed that the third most important constraint, reported by the sampled growers was lack of plant protection measure $(21.58 \%)$. Majority of growers did not know the specific pest and pesticides. They mainly depend on local vendors/ sellers which was generally not so effective for plant protection measure. Most of the growers in the study area were using their own traditional planting material since 
long and growing their crops with their indigenous knowledge, skill and their past experiences. They have little awareness regarding the improved method of cultivation. The constraints like low frequency visit by extension functionaries $(22.46 \%)$, lack of interest of extension personnel and credible source of knowledge \& information were faced by majority of the respondents.

The constraints moderately faced by the respondents lack of interest of extension personnel(23.981), Credible source of knowledge and information (25.590), Lack of facility provided by ADA/HDO/KPS (25.850), Negative attitude of extension worker to the farmers problems (25.885), High cost of labour (28.259), Lack of time (28.892), Lack of incentives (28.969) Lack of government support/Bank loan (29.281), Inadequate transport/ storage facility (37.449), Lack of skilled labour (37.589). The least important constraints as mentioned by less number of farmers were, lack of farmer association/ organization (39.161), Lack of suitable and own land of farmers (44.207), Lack of storing facility (46.533) followed by in- adequate procurement price (54.469). The similar findings have been reported by Acharjee (1992).

In conclusion, the study indicated that inadequate information regarding Betel vine cultivation management in the sampled areas, almost sent percent growers using their own traditional knowledge in their field. They have little awareness regarding the improved method of cultivation. Lack of adequate knowledge is the most important constraint faced by the betel vine cultivators to enhance their production. High cost of Baroj construction, Lack of plant protection measure, Low frequency of diagnostic field visit of government officials, natural calamities, lack of interest of Extension personnel were the other most important constraints faced by the betel vine growers Price fluctuation was the most important constraints faced by the betel vine cultivators to realise remunerative return to the investment on betel vine cultivation. Unauthorized deductions by the traders, middleman and (commission agents) non availability of storage facilities were other pertinent problems faced by the famers. Based on the study following recommendations are made for enhancing the profitably of betel vine cultivation in the study area that the farmers should have easy access to information in related to production management and marketing aspects. Establishment of market information system to forecast the price in a-priori and simultaneously exploring the export market might be useful for realising better return from betel vine cultivation. It is also inferred that young farmers are quite enthusiastic to cultivate the betel vine and promotion of this cash crop should be continued in other parts of the Nadia districts for employment generation to enhance farmer's income from betel vine cultivation.

\section{References}

Acharjee, S.K. (1992). Study on the relationship of some socio cultural and economic characteristics with modernization of Betel vine Dept. of Agril. Extension, unpublished $\mathrm{Ph}$. D Thesis.

BalaSubrahmanyam, M.H, Balchandra, P. and Mathirajan (2005). Technological innovations in small scale industries: case studies of two foundries in Karnataka. South Asian Journal of Management, 11(3), 111-120.

Chandra, G. and Sagar, R. L. (2004). Harvesting green gold: Cultivation of betelvine in sundarban. Indian Farmers Digest, 37(3), 5-13.

Garrett, H. E. and Woodworth, R. S. (1969). 
Statistics in Psychology and Education, Feffer and Simons Pvt. Ltd., Vakils, P: 329.

Guha . P. (2004). Development of technology for enhancing shelf life of Betel leaves, Annual report of All India Coordinated Research Project on post harvest technology (ICAR). IIT, Kharagpur (Ed), Food and Agriculture Engineering Department, IIT, Kharagpur, India, pp 39-56.

Guha, P. (2006). Betel Leaf: The Neglected Green Gold of India. Journal of Human Ecology, 19 (2): 87-93.

Gupta, J, (1998). A study of the information management in diary knowledge information system, Ph.D. thesis.

Kumar, P , Pandey, A. K. And Das, S. (2018). Epidemiological Factors Affecting Phytopthora Leaf rot and Anthracnose leaf Spot Diseases of Betel vine (Piper betle) and their Control, International Journal of Current Microbiology and Applied, Science (7): 4610-4616.

Lahiri, D. (2000). "Marketing of Betel Leaves in Midnagpur District, West Bengal", Indian Journal of Agricultural Marketing, p.112.
Mandal, Subhasis, S.K. Sarangi, D. Burman, B.K. Bandyopadhyay, B. Maji, U.K. Mandal and D.K. Sharma (2013). Land Shaping Models for Enhancing Agricultural Productivity in Salt Affected Coastal Areas of West Bengal -An Economic Analysis, (3): 389-401.

Pal, P.P. (1999). Information seeking behaviour of tribal farmers of Meghalaya, Indian Journal of Hill Farming, 12(1-2): 124-125.

Rao, N. H. (2006). A framework for implementing information and communication technologies in agricultural development in India. Technological Forecasting and Social Change 74(4): 491-518.

Saha, (2001). An Analysis of the Dairy Knowledge Information System in Birbhum, West Bengal. MSc. Thesis, NDRI, Karnal, Haryana.

Van Beek, P.G.H. (1991). The Queensland Dairy AKIS. Proceedings of European Seminar on Knowledge Management and Information Technology, Agril. University, Wageni.

\section{How to cite this article:}

Manaranjan Biswas Anindita Saha and Samir Ranjan Dash. 2019. Constraints Faced by the Betel Vine Growers in Nadia District of West Bengal, India. Int.J.Curr.Microbiol.App.Sci. 8(04): 80-85. doi: https://doi.org/10.20546/ijcmas.2019.804.010 